\title{
Acaricidal activity of the organic extracts of thirteen South African plants against Rhipicephalus (Boophilus) decoloratus (Acari: Ixodidae)
}

Gerda Fouche, ${ }^{* 1}$ Mary Ramafuthula, ${ }^{1}$ Vusi Maselela, ${ }^{1}$ Moses Mokoena, ${ }^{1}$ Jeremiah Senabe, ${ }^{1}$ Tlabo Leboho, ${ }^{1}$ Bellonah M. Sakong, ${ }^{2}$ Olubukola T. Adenubi, ${ }^{2}$ Jacobus N. Eloff ${ }^{2}$ and Kevin W. Wellington, ${ }^{1 *}$

*G.fouche@csir.co.za

*kwellington@csir.co.za; kwwellington@gmail.com

${ }^{1}$ CSIR Biosciences, Pretoria, South Africa

${ }^{2}$ Phytomedicine Programme, Department of Paraclinical Sciences, Faculty of Veterinary Sciences, University of Pretoria, Onderstepoort 0110, South Africa.

\section{Highlights}

- The African blue tick, R. (B.) decoloratus, is found in Africa and Asia.

- This tick affects cattle production as well as vector pathogens.

- The extracts of two plants species have potent activity against $R$. (B.) decoloratus.

- The extracts of these plants species have low toxicity against Vero cells.

\begin{abstract}
The African blue tick, Rhipicephalus (Boophilus) decoloratus, is a common tick species found in South Africa and affects cattle production as well as vectoring pathogens in regions of Africa and Asia. In an attempt to develop a non-toxic, lower cost and environmentally friendly tick control method, twenty-six plant extracts were prepared from thirteen plant species using $99.5 \%$ acetone and 99\% ethanol. The adapted Shaw Larval Immersion Test (SLIT) was used to test the efficacy of the extracts. A $1 \%$ solution of each of the plant extracts was prepared for efficacy testing and the ethanol extracts were found to have better acaricidal activity than the acetone extracts. The ethanol extract from the leaves and flowers of Calpurnia aurea had the best activity
\end{abstract}


[Corrected Mortality $(\mathrm{CM})=82.9 \%$ ] which was followed by the stem extract of Cissus quadrangularis $(\mathrm{CM}=80.4 \%)$. The plant species were screened against Vero cells and were found to have low toxicity. From this study it is apparent that there is potential for the development of botanicals as natural acaricides against $R$. (B.) decoloratus.

Keywords: Rhipicephalus (Boophilus) decoloratus, acaricidal activity, SLIT bioassay, toxicity bioassay, Vero cells, acetone, ethanol.

\section{Introduction}

In the tropical regions of Africa the most vital constraints to livestock productivity have been ticks and tick-borne diseases (Uilenberg, 1982). Ticks cause severe economic losses by direct damage to skin and hides, blood loss, by reducing weight gain and also serving as vectors of infectious diseases (Ghosh and Nagar, 2014). They transmit pathogens including those that cause anaplasmosis (Anaplasma marginale) and babesiosis (Babesia bovis and B. bigemina) (Jongejan and Uilenberg, 2004).

Rhipicephalus (Boophilus) spp. ticks are typically distributed in tropical and subtropical regions of the world but some species have expanded to other regions due to changes in climatic conditions (Estrada-Peña et al., 2006). The African blue tick, Rhipicephalus (Boophilus) decoloratus, is a common tick species found in South Africa (Marufu et al., 2011) and affects cattle production as well as vectoring pathogens in regions of Africa and Asia (Estrada-Peña et al., 2006).

Ticks have few natural enemies and therefore tick infestations have been difficult to control (De la Fuente and Kocan, 2006). Acaricides are chemicals that are used to control 
ectoparasites. Amongst these are synthetic pyrethroids, organophosphates, formamidines and macrocyclic lactones which are widely used to manage ectoparasites. The purpose of these chemicals is to prevent direct damage and disease epidemics by keeping the populations below a critical threshold level. These chemicals cause severe ecological complications since they are non-specific, they kill non-target organisms in addition to threatening human health owing to toxic residues present in meat and milk (Graf et al., 2004). In an attempt to control ticks on cattle hundreds of gallons of residues (3-4 liters of solution per animal) are produced from these chemicals. The latter are often discarded arbitrarily causing soil and water pollution (Gromboni et al., 2007). Ticks have become resistant to chemical acaricides due to their intensive use which have rendered chemical-based tick control programs ineffective (Rosario-Cruz et al., 2005; Rodriguez-Vivas et al., 2006).

The detrimental effects of chemical acaricides have led to an investigation of alternative eco-friendly methods of tick control such as the use of natural products. Natural product plant extracts and essential oils have noteworthy activity against both acaricide-susceptible (Borges et al., 2003; Kamaraj et al., 2010; De Souza Chagas et al., 2012; Sunil et al., 2013) and acaricideresistant (Ghosh et al., 2013) economically important tick species. It has been established that botanicals, comprising a mixture of active substances, can delay or thwart the development of resistance to herbal products (Wang et al., 2007).

In light of the above we decided to investigate thirteen South African plants to discover plant species that can be used to treat tick infestation in livestock and that could be used as an alternative to current chemical acaricides. 


\section{MATERIALS AND METHODS}

\subsection{Plant material collection}

This was based on the available literature, cited above, and ethno-veterinary usage over many years at CSIR (unpublished data); thirteen South African plants species (Aloe rupestris, Antizoma angustifolia, Calpurnia aurea, Senna italica subsp arachoides (Burch.) Lock, Cissus quadrangularis, Clematis brachiata, Cleome gynandra, Ficus sycomorus, Monsonia angustifolia, Pelargonium luridium, Schkuhria pinnata, Sclerocarya birrea and Tabernaemontana elegans) were selected.

\subsection{Production of dried ground plant material}

Plant material was dried in an oven at $30-60^{\circ} \mathrm{C}$ and a hammer mill was used to grind it to obtain fine ground plant material.

\subsection{Production of plant extracts}

The solvents, ethanol and acetone, were used to prepare extracts from each of the thirteen plant species as shown in Table 1. The ethanol extract was prepared by pouring $200 \mathrm{ml}$ of $99 \%$ ethanol onto $20 \mathrm{~g}$ ground plant material which was then stirred for 1 hour. The residue was re-extracted with the same amount of solvent once again for 1 hour and for the third time the same volume of solvent was used but the mixture was stirred overnight. The extracts were combined and the solvent evaporated on a rotary evaporator. The acetone extracts were prepared from $99.5 \%$ acetone using the same procedure as that used for the ethanol extracts. The percentage yield of plant extract was calculated by dividing the mass of plant extract by the mass of ground plant material $(20 \mathrm{~g})$ used and the value obtained was then multiplied by 100 . The results of this calculation for each of the plant extracts are shown in Table 1. 
Table 1. The plant and plant part used for the solvent extraction, plant family, the mass and percentage yield of plant extract.

\begin{tabular}{|c|c|c|c|c|}
\hline Entry & $\begin{array}{c}\text { Plant and plant part used in } \\
\text { extraction }\end{array}$ & $\begin{array}{l}\text { Plant } \\
\text { Family }\end{array}$ & Solvent & $\begin{array}{c}\text { Mass of } \\
\text { extract } \\
(\% \text { Yield })\end{array}$ \\
\hline \multirow[t]{2}{*}{1} & Aloe rupestris (leaves) & Asphodelaceae & Acetone & $1.0127 \mathrm{~g}(5 \%)$ \\
\hline & & & Ethanol & $1.0504 \mathrm{~g}(5 \%)$ \\
\hline \multirow[t]{2}{*}{2} & Antizoma angustifolia (roots) & Menispermaceae & Acetone & $1.0619 \mathrm{~g}(5 \%)$ \\
\hline & & & Ethanol & $1.1942 \mathrm{~g}(6 \%)$ \\
\hline \multirow[t]{2}{*}{3} & Calpurnia aurea (leaves, flowers) & Fabaceae & Acetone & $0.9409 \mathrm{~g}(5 \%)$ \\
\hline & & & Ethanol & $1.0442 \mathrm{~g}(5 \%)$ \\
\hline \multirow[t]{2}{*}{4} & Senna italica subsp arachoides (roots, leaves, & Leguminosae & Acetone & $1.0920 \mathrm{~g}(5 \%)$ \\
\hline & fruit) & & Ethanol & $1.0640 \mathrm{~g}(5 \%)$ \\
\hline \multirow[t]{2}{*}{5} & Cissus quadrangularis (stems) & Vitaceae & Acetone & $1.0063 \mathrm{~g}(5 \%)$ \\
\hline & & & Ethanol & $1.2449 \mathrm{~g}(6 \%)$ \\
\hline \multirow[t]{2}{*}{6} & Clematis brachiata (whole plant) & Ranunculaceae & Acetone & $1.0430 \mathrm{~g}(5 \%)$ \\
\hline & & & Ethanol & $1.0552 \mathrm{~g}(5 \%)$ \\
\hline \multirow[t]{2}{*}{7} & Cleome gynandra (leaves) & Capparidaceae & Acetone & $0.9699 \mathrm{~g}(5 \%)$ \\
\hline & & & Ethanol & $1.0745 \mathrm{~g}(5 \%)$ \\
\hline \multirow[t]{2}{*}{8} & Ficus sycomorus (bark \& stems) & Moraceae & Acetone & $1.0339 \mathrm{~g}(5 \%)$ \\
\hline & & & Ethanol & $1.0451 \mathrm{~g}(5 \%)$ \\
\hline \multirow[t]{2}{*}{9} & Monsonia angustifolia (whole plant) & Geraniaceae & Acetone & $1.0013 \mathrm{~g}(5 \%)$ \\
\hline & & & Ethanol & $1.0723 \mathrm{~g}(5 \%)$ \\
\hline \multirow[t]{2}{*}{10} & Pelargonium luridum (whole plant) & Geraniaceae & Acetone & $1.0100 \mathrm{~g}(5 \%)$ \\
\hline & & & Ethanol & $1.1146 \mathrm{~g}(5 \%)$ \\
\hline \multirow[t]{2}{*}{11} & Schkuhria pinnata (whole plant) & Asteraceae & Acetone & $1.1115 \mathrm{~g}(5 \%)$ \\
\hline & & & Ethanol & $1.1619 \mathrm{~g}(5 \%)$ \\
\hline \multirow[t]{2}{*}{12} & Sclerocarya birrea (bark, root) & Anacardiaceae & Acetone & $0.9109 \mathrm{~g}(5 \%)$ \\
\hline & & & Ethanol & $1.0673 \mathrm{~g}(5 \%)$ \\
\hline \multirow[t]{2}{*}{13} & Tabernaemontana elegans (leaves) & Apocynaceae & Acetone & $1.0023 \mathrm{~g} \mathrm{(5 \% )}$ \\
\hline & & & Ethanol & $1.0256 \mathrm{~g} \mathrm{(5 \% )}$ \\
\hline
\end{tabular}

\subsection{Ticks}

Fully engorged females of $R$. (B.) decoloratus (Acari: Ixodidae) were obtained from Clinvet International, Bloemfontein, South Africa. The strain used is susceptible to an organophosphate acaricide, chlorfenvinphos, at a field concentration of 300ppm. The ticks were washed with tap water, dried and then placed into 5 conical flasks containing 20 females each. The flasks were 
incubated at $26 \pm 2^{\circ} \mathrm{C}$ at a relative humidity of greater than $70 \%$ for oviposition and hatching. Testing was performed between 17 and 25 days post hatching. This tick species was chosen for the study because it parasitises a variety of livestock species.

\subsection{Adapted Shaw larval Immersion Test (SLIT)}

The test, originally described by Shaw (1966), was used and later modified to increase the period of larval incubation after treatment to 72 hours before the test was read (Shaw et al., 1968).

\subsubsection{Extract Preparation}

A $1 \% \mathrm{w} / \mathrm{v}$ extract dilution was prepared the day before exposure to larvae from dry concentrated extracts. Approximately $0.1 \mathrm{~g}$ of extract was weighed out and diluted in approximately $10 \mathrm{ml}$ of double-distilled $\mathrm{H}_{2} \mathrm{O}$ containing $0.02 \%$ Triton X-100 and $1 \%$ acetone (Diluent). After each dilution the solution was vortexed for 1-10 min depending on solubility and then put in an ultrasonic water bath for 10min to dissolve the extract in the diluent (Shaw, 1966). The extract in some cases was still not dissolved after this treatment and was then used as it was in the exposure of the larvae.

\subsubsection{Exposure of Larvae}

Approximately 200 larvae between 16 and 25 days post hatching, were placed between two round Whatman no 1 filter papers (diameter 120mm) to form a larvae sandwich, placed in a pie plate (diameter $140 \mathrm{~mm}$ ). Ten $\mathrm{ml}$ of a $1 \%$ solution from a plant extract was then poured over the tick sandwich to expose larvae to the solution. Each run also included a positive control (300ppm - Field concentration of Chlorfenvinphos - Supadip 30\% w/v) and a negative control (diluent). After 30 minutes, excess solution was drained from the filter paper sandwich and it was transferred to a clean filter paper (Whatman no 1, diameter $250 \mathrm{~mm}$ ), opened and each half of the 
sandwich was placed on a dry spot on the larger filter paper. Approximately 100 larvae were then brushed from each half of the sandwich into a clean filter paper envelope, which was crimped closed and placed into an incubator at a temperature of $26^{\circ} \mathrm{C} \pm 2{ }^{\circ} \mathrm{C}$ and $\mathrm{RH} \geq 70 \%$ (Shaw, 1966). After 72 hours the number of live vs. dead larvae was counted and efficacy of extract to kill the larvae was determined against a negative control sample (diluent) (Shaw et al., 1968). For each plant extract the incubation was done in duplicate. The Corrected Mortality (CM) was then calculated followed by the calculation of the mean CM of each plant extract.

\subsubsection{Determination of the acaricidal activity of the plant extracts}

Corrected mortality was calculated by making use of Abbott's formula i.e.:

$$
\begin{aligned}
& \mathrm{CM} \%=[\% \mathrm{i}-\% \mathrm{c} / 100-\% \mathrm{c}] \times 100 \\
& \text { Where } \% \mathrm{i}=\% \text { mortality in test extract } \\
& \% \mathrm{c}=\% \text { mortality in negative solvent control (Diluent) } \\
& \mathrm{CM} \%=\text { corrected mortality }
\end{aligned}
$$

\subsection{Determination of the toxicity of the plant extracts}

Vero African Green monkey kidney cells are generally regarded as the first cell line to use for testing cellular toxicity (Fernández Freire et al., 2009). The plant extracts were therefore screened against these cells using the tetrazolium-based (MTT) colorimetric assay to determine the cell viability (Mosmann, 1983; McGaw et al., 2007). Each of the plant extracts were redissolved in their extracting solvents (acetone or ethanol) and tested at a concentration range of 1 to $0.001 \mathrm{mg} / \mathrm{ml}$. Doxoribicin was used as a control. The concentration of each plant extract was tested in quadruplicate and the assays repeated three times. A plant extract having a $\mathrm{LC}_{50}$ value 
less than $20 \mu \mathrm{g} / \mathrm{ml}$ is regarded as toxic and therefore an acceptable level of toxicity is a $\mathrm{LC}_{50}$ value greater than $20 \mu \mathrm{g} / \mathrm{ml}$ (Kuete and Efferth, 2010).

\subsubsection{Statistical analysis}

The experiment for the determination of the cytotoxicity was done in triplicate. The cytotoxicity results were expressed as mean \pm standard deviation (SD) of the three replicates. $P$ values of $<$ 0.05 were regarded as significant.

\section{Results}

\subsection{Determination of the acaricidal activity}

The adapted Shaw Larval Immersion Test (SLIT) was used to determine the acaricidal activity of the plant extracts (Shaw, 1966). For efficacy testing the larvae of $R$. (B.) decoloratus were exposed to a $1 \%$ solution $(0.1 \mathrm{~g}$ per $10 \mathrm{ml})$ of each of the plant extracts. The results are shown in Table 2. None of the acetone extracts produced mortality greater than 50\%. Ethanol extracts of C. aurea (leaves, flowers) had the best activity $(\mathrm{CM}=82.9 \%)$ followed by $C$. quadrangularis $(\mathrm{CM}=80.4 \%)$.

\subsection{Determination of the toxicity of the plant extracts}

The results are shown in Table 2. From these results it is evident that none of these plant extracts could be classified as toxic since their $\mathrm{LC}_{50}$ values were greater than $20 \mu \mathrm{g} / \mathrm{ml}$. Only the control, Doxorubicin $\left(\mathrm{LC}_{50}=2.97 \pm 0.016 \mu \mathrm{g} / \mathrm{ml}=5.12 \pm 0.028 \mu \mathrm{M}\right)$, had a $\mathrm{LC}_{50}$ value less than 20 $\mu \mathrm{g} / \mathrm{ml}$ and was the most toxic.

For the acetone extracts, C. gynandra was the least toxic $\left(\mathrm{LC}_{50}=553.61 \mu \mathrm{g} / \mathrm{ml}\right)$ followed by $F$. sycomorus $\left(\mathrm{LC}_{50}=172.94 \mu \mathrm{g} / \mathrm{ml}\right)$. Amongst the ethanol extracts Senna italica subsp 
Table 2. The corrected mortality $(\mathrm{CM})$ and concentration in $\mathrm{mg} / \mathrm{ml}$ killing $50 \%$ of Vero cells $\left(\mathrm{LC}_{50}\right)$ of the thirteen indigenous South African plant species screened against $R$. (B.) decoloratus.

\begin{tabular}{|c|c|c|c|c|c|}
\hline Entry & $\begin{array}{l}\text { Plant and plant part } \\
\text { used in extraction }\end{array}$ & Solvent & $\begin{array}{c}\text { Mortality } \\
\quad(\%)\end{array}$ & $\begin{array}{l}\mathrm{CM} \\
(\%)\end{array}$ & $\begin{array}{c}\text { Vero cells } \\
\mathrm{LC}_{50}(\mu \mathrm{g} / \mathrm{ml})\end{array}$ \\
\hline \multirow[t]{2}{*}{1} & Aloe rupestris (leaves) & Acetone & 31.7 & 23.6 & $63.46 \pm 11.00$ \\
\hline & & Ethanol & 13.6 & 3.4 & $101.99 \pm 3.86$ \\
\hline \multirow[t]{2}{*}{2} & Antizoma angustifolia (roots) & Acetone & 11.7 & 1.9 & $43.59 \pm 6.28$ \\
\hline & & Ethanol & 20.1 & 10.6 & $24.30 \pm 0.22$ \\
\hline \multirow[t]{2}{*}{3} & Calpurnia aurea (leaves, flowers) & Acetone & 11.3 & 0.8 & $166.63 \pm 7.97$ \\
\hline & & Ethanol & 84.7 & 82.9 & $504.32 \pm 3.90$ \\
\hline \multirow[t]{2}{*}{4} & Senna italica subsp arachnoides (roots, leaves, fruit) & Acetone & 9.3 & 0.0 & $46.31 \pm 2.89$ \\
\hline & & Ethanol & 19.3 & 9.7 & $550.67 \pm 12.49$ \\
\hline \multirow[t]{2}{*}{5} & Cissus quadrangularis (stems) & Acetone & 26.0 & 17.2 & $41.44 \pm 2.96$ \\
\hline & & Ethanol & 82.6 & 80.4 & $74.33 \pm 3.68$ \\
\hline \multirow[t]{2}{*}{6} & Clematis brachiata (whole plant) & Acetone & 24.3 & 15.3 & $117.00 \pm 4.08$ \\
\hline & & Ethanol & 36.5 & 28.9 & $485.28 \pm 21.74$ \\
\hline \multirow[t]{2}{*}{7} & Cleome gynandra (leaves) & Acetone & 15.8 & 5.8 & $553.61 \pm 18.83$ \\
\hline & & Ethanol & 26.5 & 17.8 & $39.51 \pm 0.36$ \\
\hline \multirow[t]{2}{*}{8} & Ficus sycomorus (bark \& stems) & Acetone & 12.2 & 1.8 & $172.94 \pm 8.91$ \\
\hline & & Ethanol & 14.1 & 3.9 & $458.36 \pm 7.87$ \\
\hline \multirow[t]{2}{*}{9} & Monsonia angustifolia (whole plant) & Acetone & 19.1 & 9.5 & $120.37 \pm 4.06$ \\
\hline & & Ethanol & 20.0 & 10.5 & $34.67 \pm 0.86$ \\
\hline \multirow[t]{2}{*}{10} & Pelargonium luridum (whole plant) & Acetone & 46.1 & 39.7 & $30.58 \pm 3.40$ \\
\hline & & Ethanol & 26.0 & 17.2 & $32.86 \pm 1.06$ \\
\hline \multirow[t]{2}{*}{11} & Schkuhria pinnata (whole plant) & Acetone & 9.6 & 0.0 & $39.93 \pm 1.80$ \\
\hline & & Ethanol & 21.9 & 12.6 & $89.14 \pm 4.14$ \\
\hline \multirow[t]{2}{*}{12} & Sclerocarya birrea (bark, root) & Acetone & 42.7 & 35.9 & $418.27 \pm 7.89$ \\
\hline & & Ethanol & 15.2 & 5.1 & $486.71 \pm 3.11$ \\
\hline \multirow[t]{2}{*}{13} & Tabernaemontana elegans (leaves) & Acetone & 14.0 & 3.8 & $32.35 \pm 0.88$ \\
\hline & & Ethanol & 16.7 & 6.8 & $40.04 \pm 4.78$ \\
\hline 14 & Diluent (negative control) & - & 10.6 & - & - \\
\hline 15 & Chlorfenvinphos & - & 99.0 & 99.0 & - \\
\hline 16 & Doxorubicin & - & - & - & $2.97 \pm 0.016$ \\
\hline
\end{tabular}

Negative control: consisted of only diluent (used to prepare extractions)

Positive Control: $300 \mathrm{ppm}$ (Field concentration of Chlorfenvinphos) Supadip 30\% m/v $\mathrm{CM}=$ corrected mortality 
arachoides was the least toxic $\left(\mathrm{LC}_{50}=550.67 \pm 12.49 \mu \mathrm{g} / \mathrm{ml}\right)$ followed by $C$. aurea $\left(\mathrm{LC}_{50}=\right.$ $504.32 \pm 3.90 \mu \mathrm{g} / \mathrm{ml})$. T. elegans $\left(\mathrm{LC}_{50}=32.35 \mu \mathrm{g} / \mathrm{ml}\right)$ and $S$. pinnata $\left(\mathrm{LC}_{50}=39.93 \mu \mathrm{g} / \mathrm{ml}\right)$ were the most toxic to the cells.

\section{Discussion}

From the results of the efficacy testing against $R$. (B.) decoloratus it was evident that two plant species had excellent acaricidal activity (Table 2) while the rest of the plant species had lower activity. Acaricidal activity was observed for the ethanol extracts and not for the acetone extracts. The activity of the plant extracts were compared to that of the acaricide, chlorfenvinphos, which was used as a positive control (Mekonnen et al., 2003).

The ethanol extract from $C$. aurea (leaves, flowers) had excellent acaricidal activity (CM $=82.9 \%)$ while the acetone extract had no activity $(\mathrm{CM}=0.8 \%)$ against $R$. (B.) decoloratus.

It was anticipated that the acetone extracts would have activity because Zorloni et al. (2010) reported that $20 \%$ and $10 \%$ acetone extracts for $C$. aurea (leaves) either kill or severely compromise the mobility of unfed adult Rhipicephalus pulchellus ticks.

It was suggested that extracts from $C$. aurea can potentially be used as baits in a trap for the control of ticks in the field (Nana et al., 2010). In this study experiments were conducted to investigate the response of two tick species (Rhipicephalus pulchellus Gerstaker, 1873 and Rhipicephalus appendiculatus Neumann, 1901) to three different dried leaf extracts (acetone, aqueous and oil) of $C$. aurea (Aiton) Benth. The attraction-aggregation attachment pheromone (AAAP) was used as the positive control in the study. It was found that the activity of the oil extract was comparable to $47.8 \%$ of the activity of the pheromone.

Phenolic compounds were identified as the main chemical constituents of C. aurea (Adedapo et al., 2008) that are thought to be responsible for the attraction of over twelve species 
of ixodid ticks (Wood et al., 1975; Yoder and Stevens, 2000). The efficacy of the ethanol extract of $C$. aurea (leaves, flowers) may thus be due to its ability to attract, and also both kill or severely compromise the mobility of ticks.

Zorloni (2008) conducted a study on twenty-eight plant species used to control ticks on animals in southern Ethiopia. Similar activities were found in C. aurea collected from Ethiopia and South Africa growing under widely different environmental conditions.

The acetone and ethanol extract (roots, leaves, fruit) of $S$. italica subsp arachoides did not have acaricidal activity (acetone extract: $\mathrm{CM}=0.0 \%$; ethanol extract: $\mathrm{CM}=9.7 \%$ ). This is in contrast to other reports for which acaricidal activity was reported.

Magano et al. (2008) reported that the root extracts of S. italica subsp arachoides (Burch.) Lock had acaricidal activity against adults of Hyalomma rufipes. Only the ethyl acetate extract was potent against adults of $H$. rufipes of the hexane, chloroform, dichloromethane, ethyl acetate and methanol extracts tested.

The acetone extract of $C$. quadrangularis (stem) had no activity $(\mathrm{CM}=17.2 \%)$ against $R$. (B.) decoloratus larvae while the activity of the ethanol extract was excellent $(\mathrm{CM}=80.4 \%)$. $R$. (B.) decoloratus is susceptible to the active principles in the ethanol extract and that in the acetone extract had no effect on this tick species. Our results are in agreement with that of Santhoshkumar et al. (2012) who also reported on the acaricidal activity of $C$. quadrangularis. In their study aqueous extracts (stem) were screened against $R$. (B.) microplus. The aqueous extract (stem) attached to silver nanoparticles had better acaricidal activity against $R$. (B.) microplus than the free aqueous extract (stem). The stem of $C$. quadrangularis has two steroidal principles and two asymmetric tetracyclic triterpenoids. $\beta$-sitosterol, $\delta$-amyrin, $\delta$-amyrone, and flavonoids (quercetin) having different potential metabolic and physiological effects has also been reported 
to be present (Jainu and Devi, 2004; Jakikasem et al., 2000). There are also unique stilbene derivatives termed quadrangularins A, B and C (Adesanya et al., 1999). Phytochemical screening of the ethanolic extract of the stem of $C$. quadrangularis also revealed the presence of alkaloids, flavonoids, phenols and tannins in C. quadrangularis (Chidambara Murthy et al., 2003). The acaricidal activity observed could thus be attributed to one or several of the compounds present in the stem of $C$. quadrangularis.

For C. gynandra (leaves) both the acetone and ethanol extracts did not have activity (CM $=5.8 \%$ and $17.8 \%$ respectively). Our results are in contrast with that of Malonza et al. (1992) and Lwande et al. (1999) who both reported acaricidal activity for C. gynandra. The concentration of the plant extract $(1 \%)$ used in the determination of acaricidal activity in this present study may have been too low and the active principles in the extract of $C$. gynandra (leaves) may simply have had no effect on $R$. (B.) decoloratus and therefore no acaricidal activity was observed.

Other plant species that have acaricidal activity against $R$. (B.) decorolatus have also been documented. The neem tree (Azadirachta indica A. Juss, family: Meliaceae) is very popular in most tropical and sub-tropical regions of the world. The toxicity of neem seed oil at concentrations of $20-100 \%$ against the larvae of $R$. (B.) decoloratus in Nigeria has been documented with $100 \%$ mortality in $24-27$ hours post exposure (Choudhury, 2009). The ethanol extracts of C. quadrangularis (stem) and C. aurea (leaves, flowers) in the present study had much better acaricidal activity than neem seed oil from $A$. indica because excellent activity (mortality $>80 \%$ ) was obtained at a $1 \%$ concentration of the extracts. Traditional tick control methods used by peasant farmers to control ticks in western Ethiopia were investigated (Regassa, 2000). Latexes of Euphorbia obovalifolia and Ficus brachypoda were investigated for acaricidal 
activity. These plant preparations demonstrated high levels of efficacy in preliminary in vitro efficacy tests conducted on engorged females of $R$. (B.) decoloratus. E. obovalifolia had a mortality of $92 \%$ and F. brachypoda had a mortality of $83 \%$.

C. aurea and C. quadrangularis plant species are promising as constituents for integrated pest management systems due to being environmentally friendly, highly efficacious and having low toxicity.

\section{CONCLUSION}

C. aurea and C. quadrangularis plant species tested as a $1 \%$ solution of the plant extract have excellent acaricidal activities against $R$. (B.) decoloratus and have low toxicity against Vero cells. The isolation and identification of the compounds responsible for the acaricidal activity in these extracts will be beneficial for the discovery of novel natural acaricides. These plant species could be good alternatives in an integrated control effort against the blue tick, $R$. (B.) decoloratus, to overcome problems associated with the use of chemical acaricides.

\section{Conflict of interest}

The authors declare that they have no competing interests.

\section{Acknowledgements}

The authors thank the Technology Innovation Agency (TIA) of South Africa for financial support. 


\section{References}

Adedapo, A.A., Jimoh, F.O., Koduru, S., Afolayan, J.A., Masika, P., 2008. Antibacterial and antioxidant properties of the methanol extracts of leaves and stems of Calpurnia aurea. BMC Complement. Altern. Med. 8 (53), 1-8.

Adesanya, S.A., Nia, R., Martin, M.T., Boukamcha, N., Montagnac, A., Pais, M., 1999. Stilbene derivatives from Cissus quadrangularis. J. Nat. Prod. 62(12), 1694-1695.

Borges, L.M.F., Ferri, P.H., Silva, W.J., Silva, W.C., Silva, J.G., 2003. In vitro efficacy of extracts of Melia azedarach against the tick, Boophilus microplus. Med. Vet. Entomol. 17, 228-231.

Chidambara Murthy, K.N., Vanitha, A., Mahadeva Swamy, M., Ravishankar, G.A., 2003. Antioxidant and antimicrobial activity of Cissus quadrangularis L, J. Med. Food, 6(2), 99-105.

Choudhury, M.K., 2009. Toxicity of neem seed oil against the larvae of Boophilus decoloratus, a one-host tick of cattle. Indian J. Pharm. Sci. 71(5), 562-563.

De la Fuente, J., Kocan, K. M., 2006. Strategies for development of vaccines for control of ixodid tick species. Parasite Immunol. 28, 275-283.

De Souza Chagas, A.C.S., de Barros, L.D., Cotinguiba, F., Furlan, M., Giglioti, R., de Sena Oliveira, M.C., Bizzo, H.R. 2012. In vitro efficacy of plant extracts and synthesized substances on Rhipicephalus (Boophilus) microplus (Acari: Ixodidae). Parasitol. Res. 110, 295-303.

Estrada-Peña, A., Bouattour, A., Camicas, J.L., Guglielmone, A., Horak, I., Jongejan, F., Latif, A., Pegram, R., Walker, A.R., 2006. The known distribution and ecological preferences of the tick subgenus Boophilus (Acari: Ixodidae) in Africa and Latin America. Exp. Appl. Acarol. 38, 219-235.

Fernández Freire, P., Peropadre, A., Pérez Martín, J.M., Herrero, O., Hazen, M.J., 2009. An integrated cellular model to evaluate cytotoxic effects in mammalian cell lines. Toxicol. in Vitro 23, 1553-1558.

Graf, J.F., Gogolewski, R., Leach, B.N., 2004. Tick control: an industry point of view. Parasitology 129, S247S442. 
Ghosh, S., Nagar, G., 2014. Problem of ticks and tick-borne diseases in India with special emphasis on progress in tick control research: a review. J. Vector Borne Dis. 51, 259-270.

Ghosh, S., Tiwari, S.S., Srivastava, S., Sharma, A.K., Kumar, S., Ray, D.D., Rawat, A.K.S., 2013. Acaricidal properties of Ricinus communis leaf extracts against organophosphate and pyrethroids resistant Rhipicephalus (Boophilus) microplus. Vet. Parasitol. 192, 259-267.

Gromboni, F., Ferreira, A.G., Kamogawa, M.Y., Nogueira, A.R.A., 2007. Avaliação da reação foto-Fenton na decomposição de resíduos de carrapaticida. Quím Nova, São Paulo 30, 264-267.

Jainu, M., Devi, C.S., 2004. Effect of Cissus quadrangularis on gastric mucosal defensive factors in experimentally induced gastric ulcer - a comparative study with Sucralfate. J. Med. Food 7(3), 372-376.

Jakikasem, S., Limsiriwong, P., Kajsongkarm, T., Sontorntanasart, T., Phytochemical study of Cissus quadrangularis. Thai J. Pharm. Sci., 2000, 24, 25.

Jongejan, F., Uilenberg, G., 2004. The global importance of ticks. Parasitology 129 (Suppl), S3-S14.

Kamaraj, C., Rahuman, A.A., Bagavan, A., Elango, G., Rajakumar, G., Zahir, A.A., Marimuthu S., Santhoshkumar, T., Jayaseelan, C., 2010. Evaluation of medicinal plant extracts against blood-sucking parasites. Parasitol. Res. 106, $1403-1412$.

Kuete, V., Efferth, T., 2010. Cameroonian medicinal plants: pharmacology and derived natural products. Frontiers Pharmacol., 1, 123.

Lwande, W., Ndakala, A.J., Hassanali, A., Moreka, L., Nyandat, N., Ndungu, M., Amiani, H., Gitu, P.M., Malonza, M.M., Punyua, D.K., 1999. Gynandropsis gynandra essential oil and its constituents as tick (Rhipicephalus appendiculatus) repellents. Phytochemistry 50, 401-405.

Magano, S.R., Thembo, K.M., Ndlovu, S.M., Makhubela, N.F.H., 2008. The anti-tick properties of the root extracts of Senna italica subsp. Arachoides. Afr. J. Biotechnol. 7(4), 476-481. 
Marufu, M.C., Chimonyo, M., Mapiye, C., Dzama, K., 2011. Tick loads in cattle raised on sweet and sour rangelands in the low-input farming areas of South Africa. Trop. Anim. Hlth Prod. 43, 307-313.

Malonza, M.M., Dipeolu, O.O., Amoo, A.O., Hassan, S.M., 1992. Laboratory and field observations on anti-tick properties of the plant Gynandropsis gynandra (L.), Brig., Vet. Parasitol. 42, 123-136.

McGaw, L.J., Steenkamp, V., Eloff, J.N., 2007. Evaluation of Athrixia bush tea for cytotoxity, antioxidant activity, caffeine content and presence of pyrrolizidine alkaloids. J Ethnopharmacol. 110, 16-22.

Mekonnen, S., Bryson, N.R., Fourie, L.J., Peter, R.J., Spickett, A.M., Taylor, R.J., Strydom, T., Kemp, D.H., Horak, I.G., 2003. Comparison of 3 tests to detect acaricide resistance in Boophilus decoloratus on dairy farms in the Eastern Cape Province, South Africa. S. Afr. Vet. Ass. 74(2): 41-44.

Mosmann, T., 1983. Rapid colorimetric assay for cellular growth and survival: application to proliferation and cytotoxicity assays. J. Immunol. Methods, 65(1-2), 55-63.

Nana, P., Maniania, N.K., Maranga, R.O., Kutima, H.L., Boga, H.I., Nchu, F., Eloff, J.N., 2010. Attraction response of adult Rhipicephalus appendiculatus and Rhipicephalus pulchellus (Acari: Ixodidae) ticks to extracts from Calpurnia aurea (Fabaceae). Vet. Parasitol. 174, 124-130.

Regassa, A., 2000. The use of herbal preparations for tick control in western Ethiopia. J. S. Afr. Vet. Ass. 71(4), $240-243$.

Rodriguez-Vivas, R.I., Alonso-Diaz, M.A., Rodriguez-Arevalo, F., Fragoso-Sanchez, H., Santamaria, V.M., Rosario-Cruz, R., 2006. Prevalence and potential risk factors for organophosphate and pyrethroid resistance in Boophilus microplus ticks on cattle ranches from the state of Yucatan, Mexico. Vet. Parasitol. 136, $335-343$.

Rosario-Cruz, R., Guerrero, F.D., Miller, R.J., Rodriguez-Vivas, R.I., Dominguez-Garcia D.I., Cornel, A.J., Hernandez-Ortiz, R., George, J.E. 2005. Roles played by esterase activity and by a sodium channel mutation involved in pyrethroid resistance in populations of Boophilus microplus (Acari: Ixodidae) collected from Yucatan, Mexico. J. Med. Entomol. 42, 1020-1025. 
Santhoshkumar, T., Rahuman, A.A., Bagavan, A., Marimuthu, S., Jayaseelan, C., Kirthi, A.V., Kamaraj, C., Rajakumar, G., Zahir, A.A., Elango, G., Velayutham, K., Iyappan, M., Siva, C., Karthik, L., Rao, K.V.B., 2012. Evaluation of stem aqueous extract and synthesized silver nanoparticles using Cissus quadrangularis against Hippobosca maculata and Rhipicephalus (Boophilus) microplus. Exp. Parasitol. 132, 156-165.

Shaw, R.D., 1966. Culture of organophosphorus resistant strain of Boophilus microplus (Can,) and an assessment of its resistance spectrum. Bull. Entomol. Res. 56, 389-405.

Shaw, R. D., Cook, M., Carson, R. E., 1968. Developments in the resistance status of the southern cattle tick to organophosphorus and carbamate insecticides. J. Econ. Entomol. 61, 1590-1594.

Sunil, A.R., Amithamol, K.K., Juliet, S., Nair, S.N., Ajithkumar, K.G., Soorya, V.C., Divya, T.M., Jyothymol, G., Ghosh, S., Ravindran, R., 2013. Acaricidal effect of Cassia fistula Linn. leaf ethanolic extract against Rhipicephalus (Boophilus) annulatus. Trop. Biomed. 30, 231-237.

Wang, Y.N., Shi, G.L., Zhao, L.L., 2007. Acaricidal activity of Juglans regia leaf extracts on Tetranychus viennensis and Tetranychus cinnabarinus (Acaris: Tetranychidae). J. Econ. Entomol. 100, 1298-1303.

Uilenberg, G., 1982. Disease problems associated with the introduction of European cattle in the tropics, Proc.12th World Congress on Diseases of Cattle. Amsterdam,Vol II, pp.1025-1032.

Wood, W.F., Leahy, S.M.G., Galun, R., Prestwich, G.D., Meinwald, J., Purnell, R.E., Payne, R.C., 1975. Phenols as pheromones of ixodid ticks: a general phenomenon? J. Chem. Ecol. 1 (4), 501-509.

Yoder, J.A., Stevens, W.B., 2000. Attraction of immature stages of the American dog tick (Dermacentor variabilis) to 2,6-dichlorophenol. Exp. Appl. Acarol. 24, 159-164.

Zorloni, A., 2008. Evaluation of plants used for the control of animal ectoparasitoses in southern Ethiopia (Oromiya and Somali regions). M.Sc. Thesis. Phytomedicine Programme, University of Pretoria.

Zorloni, A., Penzhorn, B.L., Eloff, J.N., 2010. Extracts of Calpurnia aurea leaves from southern Ethiopia attract and immobilise or kill ticks. Vet. Parasitol. 168, 160-164. 